\title{
Arion alpinus Pollonera, 1887 in the Czech Republic (Gastropoda: Arionidae)
}

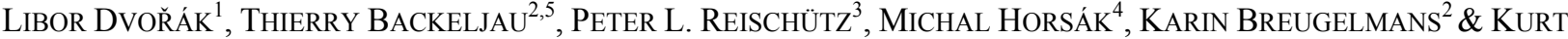 \\ JORDAENS $^{5}$ \\ ${ }^{1}$ Šumava National Park Administration, Dept. of Science and Research, Sušická 399, CZ-34192 Kašperské Hory, Czech Republic, e-mail: \\ libor.dvorak@npsumava.cz \\ ${ }^{2}$ Royal Belgian Institute of Natural Sciences, Dept. of Invertebrates - Malacology Section, Vautierstraat 29, B-1000 Brussels, Belgium; e-mail: \\ Thierry.Backeljau@naturalsciences.be; Karin.Breugelmans@naturalsciences.be \\ ${ }^{3}$ Puechhaimgasse 52, A-3580 Horn, Austria, e-mail: peter.reischuetz@gmx.at \\ ${ }^{4}$ Institute of Botany and Zoology, Faculty of Science, Masaryk University, Kotlářská 2, CZ-61137 Brno, Czech Republic; e-mail. \\ horsak@sci.muni.cz \\ ${ }^{5}$ Evolutionary Biology Group, Dept. of Biology, University of Antwerp, Groenenborgerlaan 171, B-2020 Antwerp, Belgium; e-mail: \\ kurt.jordaens@ua.ac.be
}

Dvořák L., Backeljau T., Reischütz P.L., Horsák M., Breugelmans K. \& Jordaens K., 2006: Arion alpinus Pollonera, 1887 in the Czech Republic (Gastropoda: Arionidae). - Malacologica Bohemoslovaca 5: 51-55. Online serial at $<\mathrm{http}: / /$ mollusca.sav.sk $>6$-Dec-2006.

The first records of the pulmonate land snail Arion alpinus in the Czech Republic are presented and the European distribution and ecology of this species are discussed. A. alpinus occurs in forest ecosystems in the southern part of the Czech Republic at the margin of its continuous distribution range. Both externally and anatomically the Czech Republican specimens strongly resemble A. alpinus from neighbouring countries. Identification was confirmed by DNA analysis.

\section{Introduction}

Arion alpinus Pollonera, 1887 is a small Central European slug with the centre of its distribution in the Alps (REISCHÜTZ 1986). In the Czech Republic the species may be easily confused with young specimens of $A$. fuscus (Müller, 1774) or light coloured specimens of $A$. distinctus Mabille, 1868. However, A. alpinus can be distinguished from both these species by the following colour features (see Fig. 1): (1) the upper side of the body is yellowish, yellow-brownish or greenish with darker lateral stripes that do not expand under the pneumostome, (2) the yellow to light orange foot sole, (3) the pale yellow body mucus, and (4) by the anatomy of the genitalia (see Fig. 2, 5-6). This paper focusses on the occurrence of $A$. alpinus in the Czech Republic.

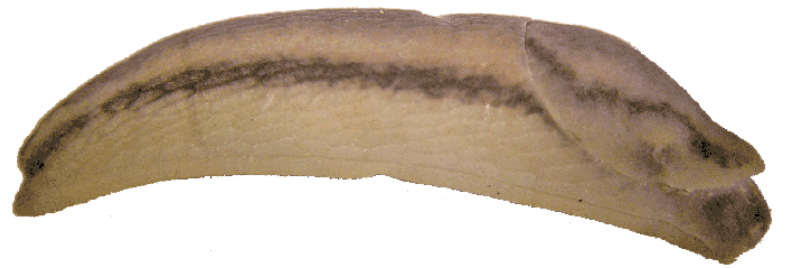

Fig. 1. Arion alpinus from locality Šebestov. Photo L. Dvořák.

\section{Localities}

For each locality where $A$. alpinus was found, the following information is given: region, locality, code of the Czech Republic grid mapping system, description of biotope, altitude and geographical coordinates (if available), collecting date, number of specimens, name of the collector, place of deposition of the specimens, and way of determination. The records of Reischütz involve: one specimen per locality, identified by external morphology only (specimens were not collected).

1. Bohemia mer.-occ., Šumava PLA, Kašperské Hory env. (6847), spruce forest in the Amálino Údolí Nature Reserve, in a small old mining, $695 \mathrm{~m}$ a.s.l., $49^{\circ} 07^{\prime} 58.98^{\prime \prime} \mathrm{N}, 13^{\circ} 33^{\prime} 46.98^{\prime \prime}$ E, 27 Oct 2000, 1 ex., L. Dvořák leg., det. anatom., M. Horsák coll.

2. Bohemia mer.-occ., Šebestov (6847), an alder pocket along the stream $\mathrm{N}$ of a village, under the bark of fallen trunks, $795 \mathrm{~m}$ a.s.1., $49^{\circ} 07^{\prime} 12.16^{\prime \prime} \mathrm{N}, 1^{\circ} 38^{\prime} 55.24^{\prime \prime} \mathrm{E}, 21$ Sep 2006, 1 ex., L. Dvořák leg. et coll., det. anatom.

3. Bohemia mer., Šumava PLA, Volary env. (7049), an alder pocket along the Volarský Potok stream, between wet leaves on the ground, $830 \mathrm{~m}$ a.s.1., $48^{\circ} 55^{\prime} 57.35^{\prime \prime} \mathrm{N}$, 135' $19.56^{\prime \prime}$ E, 12 June 2006, 1 ex., det. morphol., L. Dvořák leg. 
4. Bohemia mer., Šumava PLA, Volary env. (7049), a growth of Petasites in a spruce forest along the Volarský Potok stream, $850 \mathrm{~m}$ a.s.1., 48 56'06.82" N, 1352'07.94" E, 12 June 2006, 1 ex., L. Dvořák leg. et coll., det. anatom.

5. Bohemia mer., Český Krumlov (7151), a "mixed forest" (park) near the way from a large parking place to the castle, on mushrooms, Nov 1997, P.L. Reischütz leg. 6. Bohemia mer., between Lipno nad Vltavou and Frymburk (7351), a mixed forest, Nov 1997, P.L. Reischütz leg.

7. Bohemia mer., ca $3 \mathrm{~km}$ south of Horní Pěna (6856), a mixed forest, under wood, Sep 1996, P.L. Reischütz leg.

8. Moravia mer/occ., a spruce forest about $5 \mathrm{~km} \mathrm{~W}$ of Slavonice (6957), on mushrooms, Sep 1997, P.L. Reischütz leg.

9. Moravia occ., Žd'árské Vrchy PLA, Radostín env. (6361), a mixed forest in the Štírí Důl Nature Reserve, under a fallen trunk near a stream, 49 $40^{\prime} 6.32^{\prime \prime} \mathrm{N}$, 1551'34.4" E, 6 May 2006, 1 ex., L. Dvořák leg., det. anatom. and DNA, M. Horsák coll.

10. Moravia occ., Žd'árské Vrchy PLA, CZ, Velká Losenice env. (6461), a beech forest on stony debris in the Peperek Nature Reserve, under the bark of a fallen beech trunk, 49³4'36,48" N, 1551'49,46" E, 7 May 2006, 2 ex., M. Horsák leg. et coll., det. anatom. (anatomy see on Fig. 2)

11. Moravia mer., between Vranov nad Dyjí and Onšov (7060), spruce stand, on mushrooms, Oct 1993, P.L. Reischütz leg.

12. Moravia mer., between Šafov and Starý Petřín (7160), mixed forest near a little brook, under wood, Oct 1993, P.L. Reischütz leg.

13. Moravia mer., Podyjí NP, between Horní Břečkov and Č́ižov (7161), mixed forest, under wood, Aug 2005, P.L. Reischütz leg.

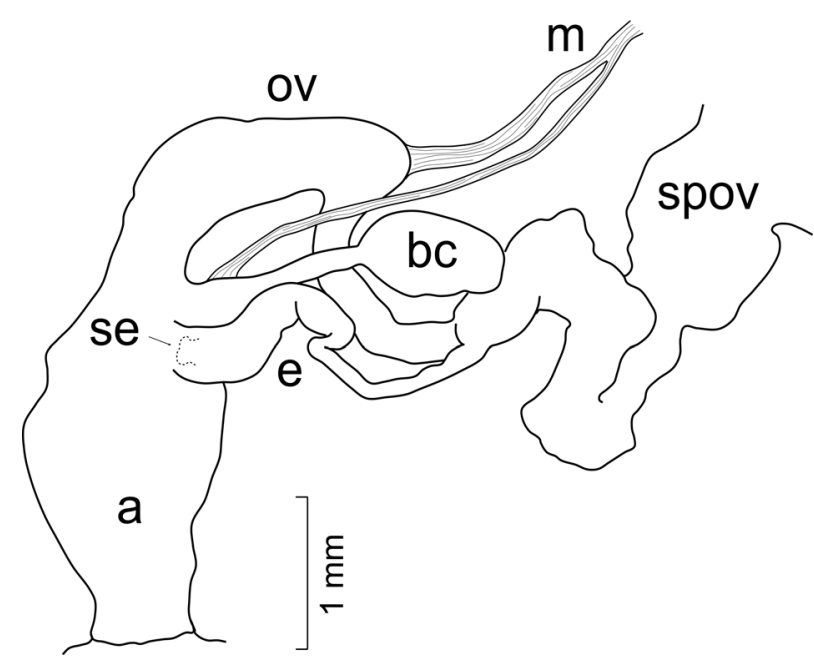

Fig. 2. Reproductive system of a young Arion alpinus from locality Peperek. Orig. M. Horsák. Abbreviations: a - atrium, $\mathrm{bc}$ - bursa copulatrix, e - epiphallus, $\mathrm{m}$ - musculus, ov - oviduct, se - position of epiphallus structure, spov - spermoviduct.

\section{Results and discussion}

\section{DNA Analysis}

Total genomic DNA was extracted from one specimen from the Radostín (6361) using the QIAamp DNA Mini Kit (Qiagen). Two mitochondrial DNA gene fragments were amplified by the Polymerase Chain Reaction (PCR), viz. a fragment of the 16S rDNA (16S) and a fragment of the cytochrome c oxidase subunit I (COI). The $16 \mathrm{~S}$ primers were:

16Sar 5'-CGCCTGTTTAACAAAAACAT-3' and 16Sbr 5'-CCGGTCTGAACTCAGATCACGT-3' (SIMON et al. 1994). The COI primers were: LCO1490 5'-GGTCAACAAATCATAAAGATATTGG-3' and HCO2198 5'-TAAACTTCAGGGTGACCAAAAAATCA-3' (FOLMER et al. 1994). The PCR reactions were performed in a total volume of $25 \mu \mathrm{l}$, containing $200 \mu \mathrm{M}$ of each dNTP, $0.2 \mu \mathrm{M}$ of each primer, 1.25 units of RDTaq ${ }^{\circledR}$ polymerase (Sigma), $10 \mathrm{mM}$ Tris- $\mathrm{HCl}$ (pH 8.3), $50 \mathrm{mM} \mathrm{KCl}, 1.1 \mathrm{mM} \mathrm{MgCl}_{2}, 0.01 \%$ gelatin (Sigma) and $2 \mu \mathrm{l}$ of template DNA. The PCR-protocol was as follows: (1) initial denaturation for $5 \mathrm{~min}$ at $95^{\circ} \mathrm{C}$; (2) then 35 cycles of $45 \mathrm{sec}$ at $95^{\circ} \mathrm{C}, 45 \mathrm{sec}$ at $50^{\circ} \mathrm{C}$ for $16 \mathrm{~S}$ or at $40^{\circ} \mathrm{C}$ for COI, $90 \mathrm{sec}$ at $72^{\circ} \mathrm{C}$; (3) final extension for $5 \mathrm{~min}$ at $72^{\circ} \mathrm{C}$. The PCR-product was purified with the Wizard ${ }^{\circledR}$ SV Gel and PCR Clean-up System (Promega) and finally sequenced using the Big Dye ${ }^{\circledR}$ Terminator v1.1 Cycle Sequencing Kit (Applied Biosystems) on an Applied Biosystem 3130 Genetic Analyzer. Sequences were checked by eye using the Chromas v1.45 software.

The two sequences of the Czech specimen were deposited in GenBank under accession numbers DQ904248 for 16S (456 base pairs) and DQ904249 for COI (611 base pairs). A BLAST search revealed that both the $16 \mathrm{~S}$ and COI sequences showed a 99-100\% match with the corresponding sequences of $A$. alpinus in GenBank, i.e. AY947346 + AY947347 for 16S and AY987867 + AY987868 for COI, in both cases Saxony (Germany) + Candriai (Italy). Phylogenetic analysis of the Czech $A$. alpinus sequences in relation to a dataset of sequences from nearly all West- and Central European arionid species, joined the Czech sequences always with $A$. alpinus from Saxony (Germany) and Candriai (Italy) with a $100 \%$ bootstrap support, irrespective of the tree reconstruction method used.

\section{Distribution}

Fig. 3 shows that $A$. alpinus is only known from the southern parts of the Czech Republic. Because the species is also known from Saxony, it may perhaps occur in northern parts of the Czech Republic too, but these regions have not been studied since $A$. alpinus has been positively identified in this country. This supports REISCHÜTZ' (1986) opinion that A. alpinus has a Central European distribution. Most records of $A$. alpinus are from Austria, where it is distributed over nearly the entire country (REISCHÜTZ 1986). Other, more peripheral localities are known from S and SE Austria, NE Italy, almost the whole of Slovenia, and W Croatia (WOLF \& 
RÄHLE 1987, WiKtoR 1996, BeCKMANN 1999, VAUPOTIČ \& VELKOVRH 2002). The Czech Republican localities reported in this study and those in Bavaria (Germany) (FALKNER 1980, 1982) are situated north to northwest of Austria. SCHNIEBS \& REISE (1997) reported the species from an isolated area in Saxony (E Germany) which is the northernmost record of $A$. alpinus (Fig. 4). Finally, there are isolated records west and northwest of Austria, i.e. SW Germany (Baden-Würtemberg) (FALK-
NER 1980), Switzerland (TURNER et al. 1998), and the French Jura (FALKNER et al. 2002). The distribution of A. alpinus in Italy is unclear since MANGANELLI et al. (1995) synonymised A. alpinus from Piemont and Lombardia with $A$. intermedius Normand, 1852, while Falkner dissected a specimen from Piemont and considered it conspecific with A. alpinus (P.L. REISCHÜTZ, pers. comm.) An overview of the European distribution of $A$. alpinus is given in Fig. 4.

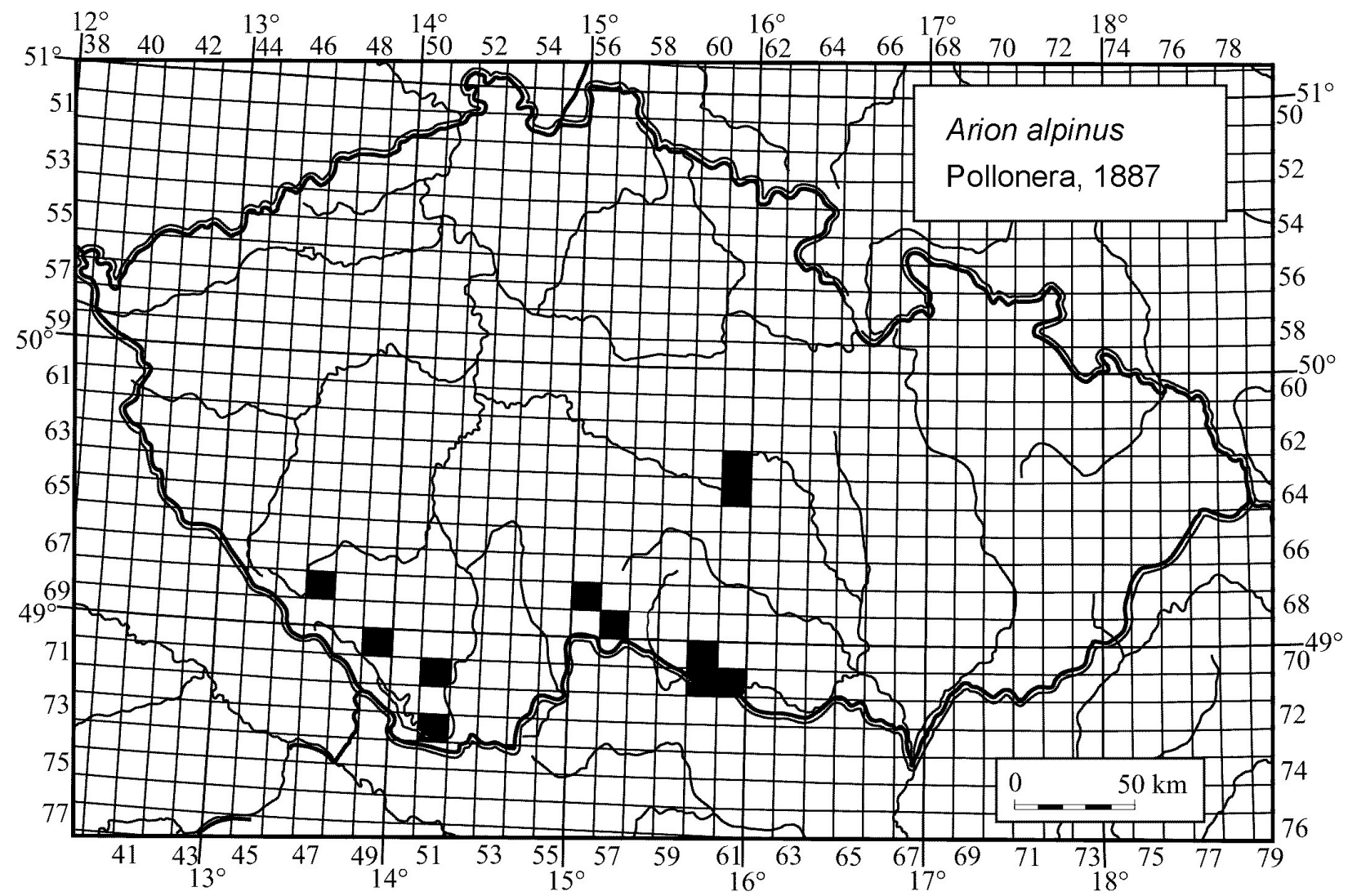

Fig. 3. Current distribution of Arion alpinus in the Czech Republic.

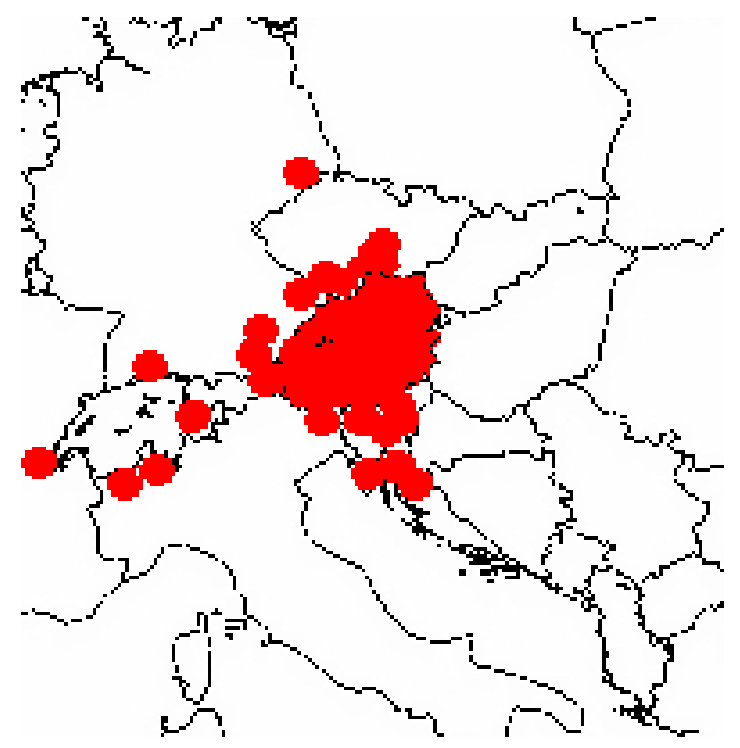

Fig. 4. Current distribution of Arion alpinus in Europe.

\section{Ecology}

All Bohemian and Moravian records are from different forest types (spruce, beech, alder, mixed, park). Many of the localities are situated in stream valleys or from other colder ecosystems. These observations correspond with previously published data (FALKNER 1980, 1982; REISCHÜTZ 1986; WIKTOR 1996). A. alpinus seems to be a typical forest species. SCHNIEBS \& REISE (1997) published their record from a patch of Acer platanoides in a larger wood dominated by conifers. A. alpinus was found here during four visits by more malacologists as T. von Proschwitz, U. Bössneck or H. Reise (H. REISE, pers. comm.). Hence, we may expect the species in other forest types as well.

A. alpinus seems predominantly a ground-dwelling species since it was mostly found on the ground under leaves, stones, and pieces of wood or bark of fallen trunks and often on mushrooms. Other authors made similar observations (FALKNER 1980, 1982; WIKTOR 1996). The localities of $A$. alpinus in the Czech Republic 
are situated at an altitude of ca. 350-850 m a.s.1. which is similar to localities of $A$. alpinus in other countries; Austria: 290-1600 m a.s.l. (REISCHÜTZ 1986), former Yugoslavia: 500-1200 m a.s.l. (predominantly 700$1000 \mathrm{~m}$ a.s.1.) (WIKTOR 1996) and Switzerland: up to $1840 \mathrm{~m}$ a.s.1. (TURNER et al. 1998). On the other hand, the locality in Saxony is situated in ca. $250 \mathrm{~m}$ a.s.l. (H. REISE, pers comm.).

Adults of $A$. alpinus are mainly found in autumn (REISCHÜTZ 1986). Records of adult $A$. alpinus from the Czech Republic are from the period August to November. Subadults were found in June at localities 2 and 3. A few individuals with relatively well-developed genitalia (see Fig. 2) were found at localities 8 and 9 in May. All juveniles and adults were found in Saxony during autumn (H. REISE, pers. comm.).

\section{Epiphallus structure}

A. alpinus can be separated from $A$. distinctus and young A. subfuscus by colour characteristics and the genitalia, even if these latter can be very similar in A. alpinus and $A$. distinctus. Yet, both species can be separated by the epiphallus structure (position see Fig. 2), which is flattened in A. alpinus, but conical in A. distinctus (see Figs 5-6).

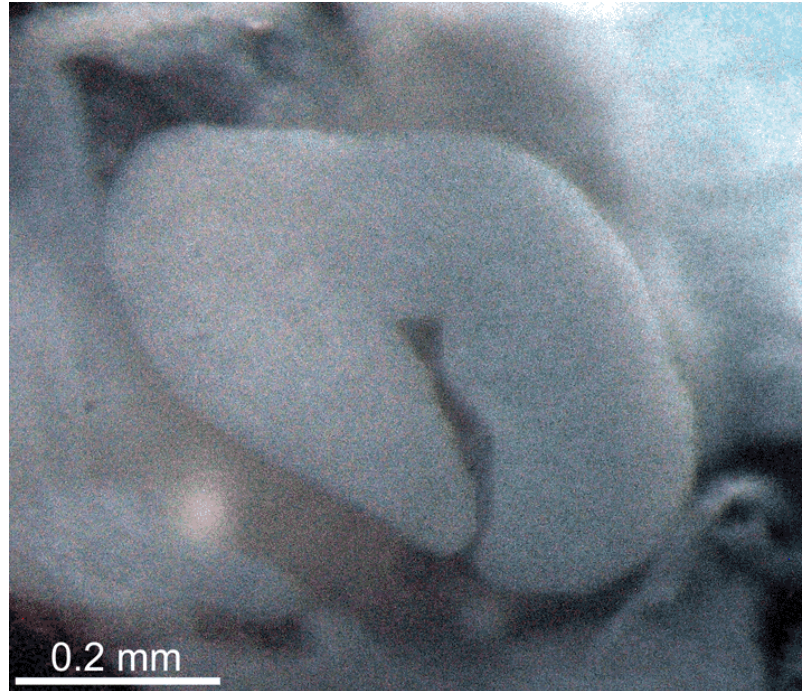

Fig. 5. Epiphallus structure of the specimen from locality Kašperské Hory. Photo: M. Horsák.

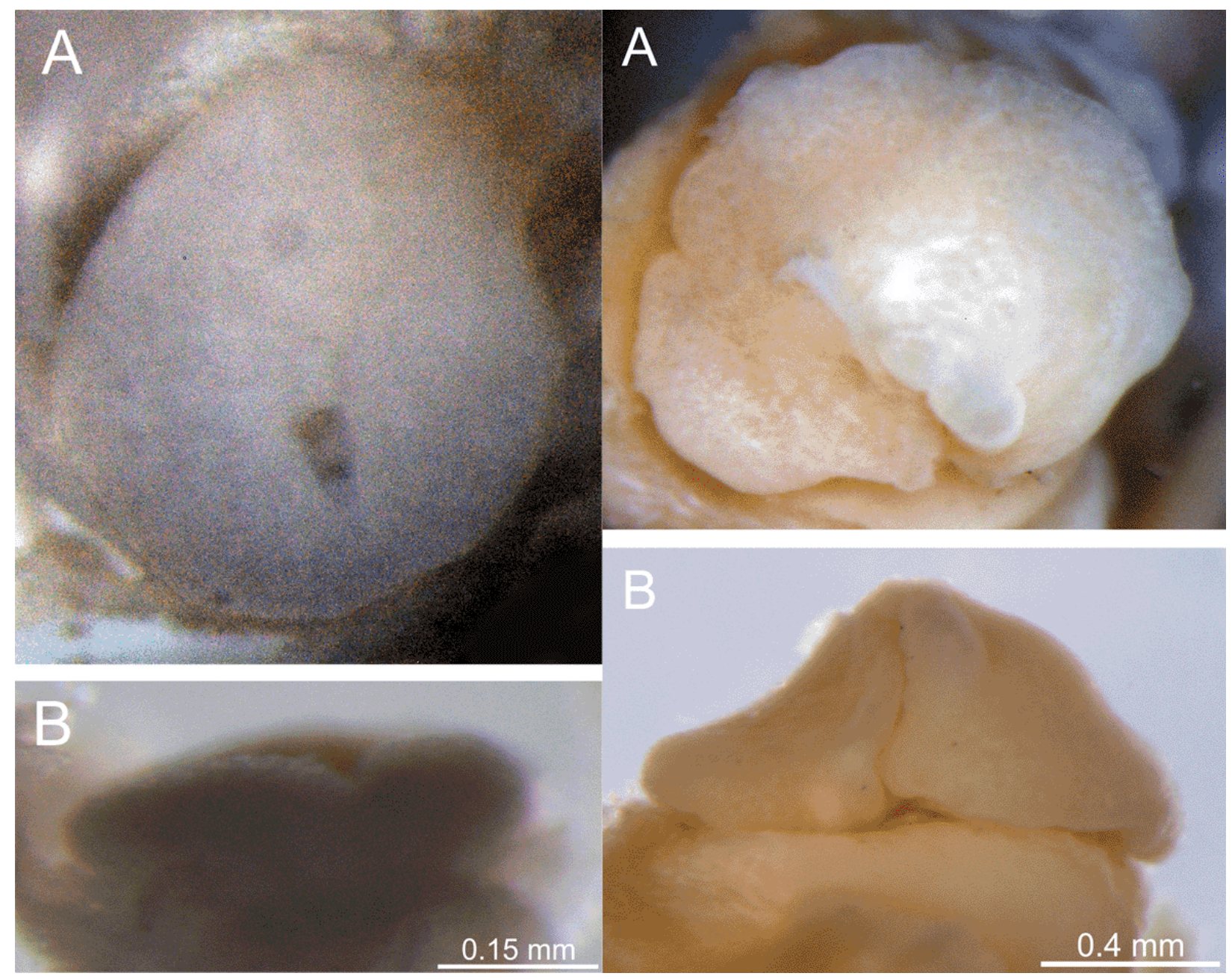

Fig. 6. Epiphallus structure from the top (A) and side (B) view. Left: Arion alpinus from locality Radostín (specimen determined by DNA). Right: Arion distinctus. Photo: M. Horsák. 


\section{Protection}

Six of the Czech Republican localities of $A$. alpinus are situated in Protected landscape areas or National parks. These localities are not exploited or intensively visited, so the known populations of $A$. alpinus are probably not endangered. However, since only (1) 13 localities are known, (2) these localities involve relatively natural forest ecosystems, and (3) the Czech localities are at the margin of the species distribution, we prefer to rank this species as Vulnerable for the Czech Republic Red List (sensu BERAN et al. 2006). The situation in Bavaria is similar where A. alpinus also occurs at the margin of its distribution range and was therefore ranked as 'Gefährdet' (Endangered) in the recent Bavarian Red List (FALKNER et al. 2003).

\section{Conclusions}

According to present knowledge, A. alpinus inhabits cold and humid forest ecosystems in the south of the Czech Republic. These records are at the northern border of the continuous distribution of this Central European slug. Adults of A. alpinus can be found from $\mathrm{Au}-$ gust till November, but individuals may already have relatively well developed genitalia in May. Since $A$. alpinus was overlooked for a long time in the Czech Republic, we suspect that the species may be more common in south Bohemia and Moravia than hitherto believed. The occurrence in the Czech Republic and Saxony suggests that the distribution of this species is not confined to the (pre-) Alps.

\section{Acknowledgements}

Authors wish to thanks H. Reise (Germany) for many helpful comments. The manuscript preparation was partly supported by the long-term research plans of Masaryk University (MSM 0021622416).

\section{References}

BeCKMANN K.-H., 1999: Die während der DMG-Tagung 1995 in Kärnten beobachteten rezenten Mollusken mit Bemerkungen zu Neunachweisen in den Untersuchungsgebieten und einem systematischen Verzeichnis (Checklist) der Kärntner Mollusken. - Mitteilungen der Deutschen malakologischen Gesellschaft, 64: 37-47.

BERAN L., JUŘIČKOVÁ L. \& HoRsÁK M., 2006: Mollusca (měkkýši), pp. 67-69. - In: Červený seznam ohrožených druhů České republiky. Beobratlí [Red list of threatened species in the Czech Republic. Invertebrates], FARKAČ J., KRÁL D. \& ŠKORPíK M. (eds) AOPK ČR, Praha, 760 pp.

FAlKNer G., 1980: Arion (Kobeltia) alpinus Pollonera in Bayern und Baden-Württemberg. - Mitteilungen der Zoologischen Gesellschaft Braunau, 3: 295-297.

FALKNER G., 1982: Weitere bayerische Fundorte von Arion (Kobeltia) alpinus Pollonera. - Mitteilungen der Zoologischen Gesellschaft Braunau, 4: 129-131.

FALKNER G., 1990: Binnenmollusken. - In: Weichtiere, FECHTER R. \& FAlKNER G. Steinbachs Naturführer, 10: 112280.

FAlkner G., Colling M., Kittel K. \& Strätz Ch., 2003: Rote Liste gefährdeter Schnecken und Muscheln (Mollusca) Bayerns. - Schriftenreihe Bayerischen Landesamt für Umweltschutz, 166: 337-347.
FALKNER G., RipKEN T.E.J. \& FALKNER M., 2002: Mollusques continentaux de France. Liste de Référence annotée et Bibliographie. - Patrimoines naturels, Paris, 52, $350 \mathrm{pp}$.

Folmer O., Black M., Hoeh W., Lutz R. \& VRiJenhoek R., 1994: DNA primers for amplification of mitochondrial cytochrome c oxidase subunit I from diverse metazoan invertebrates. - Molecular Marine Biotechnology, 3: 294-299.

Manganelli G., Bodon M., Favilli L. \& Giusti F., 1995: Gastropoda Pulmonata. - In: Checklist delle Specie della Fauna d'Italia, Minelli A., RufFo S. \& La Posta S. Fasc. 16, $59 \mathrm{pp}$.

REISCHÜTZ P.L., 1986: Die Verbreitung der Nacktschnecken Österreichs (Arionidae, Milacidae, Limacidae, Agriolimacidae, Boettgerillidae) (Supplement 2 des Catalogus Faunae Austriae). - Sitzungsberichten der Österreichischen Akademie der Wissenschaften Wien (Mathem.-naturwiss. Kl., Abt. I), 195(1/5): 67-190.

SCHNIEBS K. \& ReISE H., 1997: Auswertung des Herbsttreffens-Ost der DMG, 18.-20.10.1996 in Ottendorf (Sachsen). Erstfunde von Trichia lubomirskii und Arion alpinus. - Mitteilungen der Deutschen malakologischen Gesellschaft, 59: 33-36.

Simon C., Frati F., Beckenbach A., Crespi B., Liu H. \& FLOOK P., 1994: Evolution, weighting, and phylogenetic utility of mitochondrial gene sequences and a compilation of conserved polymerase chain reaction primers. - Annals of the Entomological Society of America, 87: 651-701.

TuRner H., Kuiper J.G.J., THEW N., BERNASCONI R., RÜETSCHI J., WÜthrich M. \& Gosteli M., 1998: Atlas der Mollusken der Schweiz und Liechtensteins. - Neuchâtel: Fauna Helvetica 2, $527 \mathrm{pp}$.

VAUPOTIČ M. \& VelKovRh F., 2002: Goli polži (Gastropoda: Pulmonata: Milacidae, Limacidae, Boettgerillidae, Agriolimacidae, Arionidae) Slovenije [Slugs (Gastropoda: Pulmonata: Milacidae, Limacidae, Boettgerillidae, Agriolimacidae, Arionidae) of Slovenia]. - Acta Biologica Slovenica, 45: 35-52 (in Slovenian).

WIKTOR A., 1996: The slugs of the former Yugoslavia (Gastropoda terrestria nuda - Arionidae, Milacidae, Limacidae, Agriolimacidae). - Annales Zoologici, 45: 1-110.

WOLF M. \& RÄHLE W., 1987: Ergebnisse einer Molluskenexkursion in die westlichen Julischen Alpen. - Mitteilungen der Deutschen malakologischen Gesellschaft, 41: 31-41. 